\title{
Hominid Dispersals and Asian Biogeography during the Lower and Early Middle Pleistocene, \\ c. 2.0-0.5 Mya
}

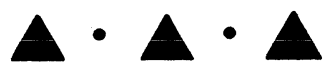

ROBIN W. DENNELL

IN RECENT YEARS, MUCH INTEREST HAS BEEN AROUSED, both publicly and academically, by the possibility that hominids may have occupied large parts of Asia by a little under two million years ago, rather than the substantially later date of around one million years ago, as was previously and commonly believed. The doubling of the antiquity of hominids in Asia has been brought about by a handful of new discoveries and the re-dating of older ones. New discoveries include the superb hominid remains and stone artifacts from Dmanisi, Georgia dated to a little under 1.8 mya (Gabunia et al. 2000a); claimed hominid remains and alleged stone artifacts from the fissure at Longgupo, China which may be as old as 1.8 mya (Huang et al. 1995); convincing examples from Riwat, Pakistan of intentionally flaked stone in a horizon dated by both the discoverers (Dennell, Rendell, and Hailwood 1988) and previous, independent geological teams (Burbank and Reynolds 1984) to the late Pliocene, c. 1.9 mya; and most importantly, the re-dating of the hominid remains from Sangiran and Mojokerto, Java to $1.81 \pm 0.04$ and $1.66 \pm 0.04$ mya (Swisher et al. 1994). The Javan dates are critically important here, for not only were these hominids long regarded as being $<1$ mya (Pope 1983), but until the discoveries at Dmanisi, they were also the only lower Pleistocene hominid remains between Southeast Asia and East Africa, some $8000 \mathrm{~km}$ to the west. Even though the dating, context, and/or identification of each of these finds has been criticized (especially Longgupo [Schwartz and Tattersall 1996]), as is also the case with other sites, such as Yiron, Israel (Ronen 1991), the suggestion that hominids first occupied Asia around 2 mya has become an almost orthodox view within paleoanthropology (e.g., Tattersall 1997).

Parallel to this interest in when Asia was first occupied, there has been similar interest in when and from where anatomically modern humans first appeared in Asia. Interpretations of mitochondrial DNA (mtDNA) data on modern humans and a small and imperfect fossil hominid sample, coming largely from Africa, have been used in conjunction to argue that modern humans originated in Africa be-

Robin W. Dennell is British Academy Research Professor at the Dept. of Archaeology, University of Sheffield, U.K. 
tween c. 100-250 kya, and eventually spread across Asia and into Australia between 60-100 kya, and also into Europe c. 30-40 kya (e.g., Stringer and McKie 1996). At the risk of generalization, this replacement hypothesis is probably more widely accepted at present than its multiregional rival, whose strongest advocates (e.g., Thorne and Wolpoff 1992) tend to emphasize the apparent discordance of the Chinese evidence with this model.

Three features mark many overviews of the first appearance of hominids and modern humans in Asia. The first is that few have paid much attention to the environmental factors that may have aided or impeded these processes of dispersal (Bar-Yosef and Belfer-Cohen [2001] and Rolland [2001] being two notable exceptions in considering issues of epidemiology and biogeography, respectively). Beyond noting that $H$. ergaster was fully bipedal and endowed with, "a typically insatiable human wanderlust" (Tattersall 1997:49), it has been assumed that only the severest of geographical obstacles might have impeded their inexorable progress across Asia. Likewise, the alleged dispersal of anatomically modern humans from Africa across the rest of the Old World is envisaged as largely unaffected by desert or rainforest, mountain or plain. Surprisingly little attempt has been made to integrate at a continental level the archaeological and fossil hominid data from Asia with the increasingly high-quality paleoclimate records from the loess sequences of North China and Central Asia. This may be because these regions were not the ones first utilized by hominids in Asia. Nevertheless, it seems unwise to ignore the best paleoclimatic Asian record simply because it is derived from areas devoid of artifacts and hominid remains. Secondly, with a few notable exceptions (e.g., Davis 1987; Bar-Yosef and Belfer-Cohen 2001), it is often implicitly assumed, in attempts to write culture histories or hominid phylogenies as continuous narratives, that initial dispersion was followed by colonization and sustained occupation (e.g., Gamble's [1995] Timewalkers: the Prehistory of Colonisation). In the Lower Pleistocene in particular, it may be more appropriate to assume that there were numerous hominid dispersal events that were geared to the most favorable environmental conditions, and to assume also that occupation was often discontinuous and intermittent, as argued for Europe before 500 kya (e.g., Dennell [1983:21-39] and Turner [1992]). Thirdly, it is customary to subdivide Eurasia longitudinally-Europe west of the Urals $\left(35^{\circ} \mathrm{E}\right)$, and Asia east or west of the Movius line, or roughly $100^{\circ} \mathrm{E}$. As argued in this paper, latitudinal divisions may be more appropriate in discussions of early hominid dispersions, with boundaries primarily between warm/hot and cool/cold environments. These boundaries would, of course, vary between glaciations and interglacials and also across Asia, because climate is not just simply a matter of latitude. Chicago and Rome, or Beijing and Naples, for example, have very different winter climates even though each pair lies on the same latitude.

This paper outlines some of the main features of hominid biogeography in Asia during the Pleistocene. It is argued that the scale of environmental, and particularly tectonic, changes across Asia during the Pleistocene have been seriously underestimated. The changes that have occurred are on a far greater scale than the repeated, but generally, similar oscillations in Europe between glacial and interglacial conditions, or the muted changes in tropical Africa. Tectonic changes were particularly dramatic, especially concerning the uplift of the Tibetan Plateau, the Himalayas-Karakorum, and the evolution of Indonesia, but there were also 
smaller changes affecting the Red Sea, the Caucasus Mountains and Caspian Sea, and the Sea of Japan. Some of these changes had major climatic consequencesparticularly the uplift of the Tibetan Plateau-and others would have affected the ease of dispersal of plants and animals, including hominids. Additionally, much greater areas of land were exposed during periods of low sea level, particularly off eastern China and Indonesia, than in Europe or Africa. Finally, there were also major climatic changes during the Pleistocene that affected the monsoonal regimes of South and East Asia, and the aridification of Central and Southwest Asia. Because of these factors, it is suggested that human occupancy in Asia before a million years ago was probably confined to warm grasslands and open woodlands that were generally south of $40^{\circ} \mathrm{N}$ in West Asia and $30^{\circ} \mathrm{N}$ in South and Southeast Asia. Hominid occupation of cool/cold grasslands further north, or at the same latitudes during cold periods, seems unlikely before the early Middle Pleistocene. Despite various recent concerns (e.g., Gamble 1999:123125) over the great differences in the timing of the first appearance of hominids in Asia and Europe (as between, for example, Dmanisi at 1.8 mya and Atapuerca TD6, Spain at 0.8 mya), the records of both continents are probably broadly similar in showing that hominids in West Asia and Europe did not persist habitually (i.e., remain in both warm and cold periods) north of $40^{\circ} \mathrm{N}$ until the Middle Pleistocene.

\section{THE LATE MIOCENE AND PLIOCENE BACKGROUND}

The onset of northern hemisphere glaciation c. 2.5 mya was preceded by a lengthy series of tectonic, oceanic, biotic, and climatic changes. The interrelationships and scale of these events are still poorly understood. In Asia, the closure of the Indonesian seaway through the northward drift of New Guinea c. 3-4 mya led to the replacement in that area of warm, South Pacific water by colder North Pacific water (Cane and Molnar 2001), and provides some background to Pliocene Asian cooling. On land, the greatest tectonic changes were the uplift of the Himalayas and the Tibetan Plateau, which had especially major long-term consequences on Asian climate.

The Tibetan Plateau, with an area of 2 million $\mathrm{km}^{2}$ and an average altitude of $5000 \mathrm{~m}$, exercises a major influence over the Asian monsoonal weather systems. Establishing at which point this plateau reached a critical altitude (very likely $2500 \mathrm{~m}$, or half the current mean elevation, according to atmospheric simulation studies [e.g., Prell and Kutzbach 1992]) that was sufficient to influence monsoonal weather systems, has proved difficult, with estimates ranging from the late Miocene to Upper Quaternary (Fort 1996). Primary indicators for the effects of the Plateau are evidence of grasslands in adjacent regions (indicating the inception of monsoonal climates), evidence of normal faulting that is only possible when present altitudes are attained, and evidence of Himalayan uplift not necessarily linked to Tibetan uplift. As Fort (1996) also indicates, it is unwise to treat areas as large and complex as Tibet or the Himalayas as homogenous features and changes in one area may not have widespread relevance or result in major climatic consequences. Nevertheless, evidence from C3/C4 analyses of soil carbonates from Pakistan indicates that grasslands became established in South Asia c. 7.0-7.4 mya (Quade and Cerling 1995), which is also when aeolian red clays were first 
deposited at Lingtai in north-central China (Ding et al. 1999). These were probably transported by westerly winds rather than northerly ones, as after 2.5 mya, and indicate that there was already an arid dust source in northern Asia. These changes have been interpreted as showing that the Tibetan Plateau was already sufficiently high in the final Miocene to contribute to global cooling and the onset of monsoonal climates (An et al. 2001). Other studies suggest later dates for these conditions. Ding and Yang (2000) indicate that grasslands at Lingtai, Central China were established only after 4.0 mya, and Wang et al. (1999) are among those suggesting that the Tibetan Plateau attained a critical height only between 5 and 8 mya.

Additionally, the east-to-west spreading of the Plateau that was a consequence of uplift appears to date from the Miocene. For example, late Miocene basin sedimentation overlies north-striking faults in the Thakkhola graben, suggesting that east-west extension had commenced by the late Miocene, while dates of 11-5 mya have been suggested for the Yangbajian graben on the western flank of the plateau. More recent ${ }^{40} \mathrm{Ar} /{ }^{39} \mathrm{Ar}$ studies of faults within the Annapurna range near the Thakkhola graben have provided a minimum age for the east-west extension of approximately 14 mya at the southern edge of the plateau (Coleman and Hodges 1995), and there is additional evidence for normal faulting in Central Tibet at 13.5 mya (Blisnuik et al. 2001). All these data suggest that the Tibetan Plateau and the Himalayas were already substantially uplifted well before the onset of global cooling at the end of the Pliocene, and some parts of southern and central Tibet may already have been at or near current altitudes.

At present, the best baseline for assessing environmental conditions at a continental level during the final Pliocene and early Pleistocene is the PRISM2 reconstruction of northern hemisphere climate and vegetation in the late Pliocene between 3.29 and 2.97 mya (Dowsett et al. 1999; see Fig. 1). As with most reconstructions of Pleistocene global climatic conditions, the primary data are from deep-sea cores, with terrestrial data incorporated when sufficiently well dated and environmentally sensitive. Asia is at present very poorly sampled, with only five sampling points between Israel and China, but certainly detail will improve as more data become available. In terms of studying human origins and dispersions, perhaps the most interesting feature of the PRISM2 reconstruction is that grasslands c. 3 mya were probably continuous from West Africa right across to northern China. In other words, the present-day desert barriers of the Sahara and Southwest Asia did not then exist. Most notably, the Red Sea barrier between Africa and Arabia would have been much less effective than now, particularly at the southern end at the Straits of Bab El Mandeb (Tchernov 1992:116-117). This might have been an important crossing point between Africa and Asia.

\section{THE ASIAN LATE PLIOCENE/EARLY PLEISTOCENE (2.5-i.8 mya)}

Almost all authors agree that there was a major global cooling event c. 2.5 mya that is most strongly indicated by the inception of northern hemisphere glaciation (Shackleton et al. 1984). This also coincided with a major cooling in the Lake Baikal region, central Siberia (Williams et al. 1997) and the onset of loess deposition in north-central China around 2.6 mya at Lingtai (Ding et al. 2000), around 


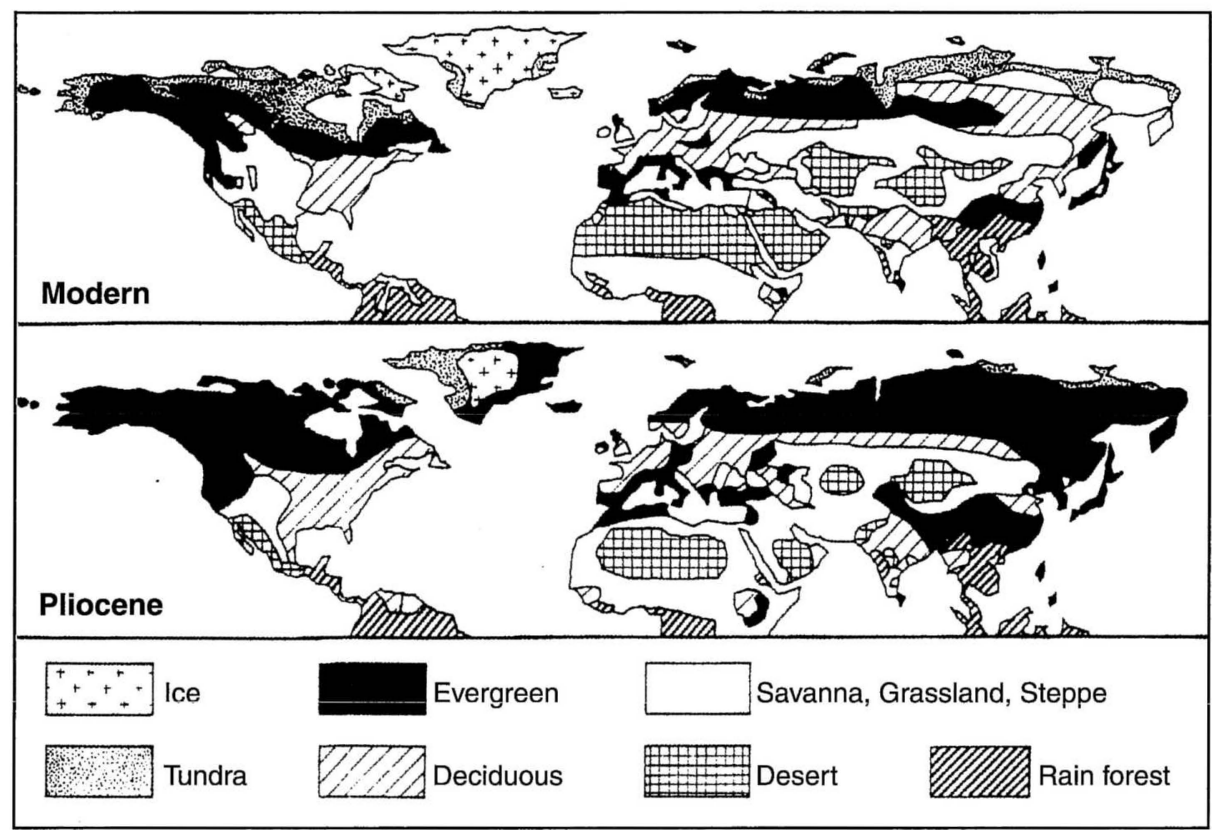

Fig. 1. Grasslands in the northern hemisphere now and in the late Pliocene, c. 3 mya. As indicated, grasslands were much more extensive than now between Africa and Asia, and there was no desert barrier between the two continents that might have impeded hominid dispersals. Early Pleistocene conditions were broadly similar to those of the late Pliocene. Source: Reprinted with permission from author (Dowsett et al. 1999).

2.47 mya at Luochuan (Lu et al. 1999), and in Central Asia at 2.5 mya (Dodonov and Baiguzina 1995). There was also a dramatic increase in the deposition of aeolian dust into the Sea of Japan c. 2.5 mya (Xiao and An 1999). In the Guanzhong and Yushe basins of central China, warm and dry conditions of the late Pliocene were replaced around this time by alternations of cold/dry conditions with a more xeric steppe vegetation, and shorter episodes of warm/wet climate with forest and grasslands (Han et al. 1997; Shi et al. 1993). These Asian changes all indicate a strengthening of the winter monsoon in East Asia, and the intensification of high pressure systems over Siberia.

The paleoenvironmental record for the early Pleistocene of southern Asia south of latitude $35^{\circ} \mathrm{N}$ is patchy, but the general picture is that the Pliocene grasslands of 3 mya were still largely in place in Southwest and South Asia, and that conditions were moister than at present. These areas are discussed in detail below.

\section{Northeast Africa and the Levant}

Extensive, moisture-induced landslides across much of the northern Sahara testify to considerably moister conditions in the late Pliocene (Busche 2001). In the northeast Sahara, the Plio-Pleistocene boundary was characterized by a relatively moist climate supporting the growth of conifers and the formation of carbonate sediments. For much of the Plio-Pleistocene, the main part of the Nile draining 
northern Ethiopia and eastern Sudan flowed eastward to the Red Sea, and was thus less of a barrier to faunal migrations between Africa and Asia (Butzer and Hansen 1968). Current evidence indicates that the environment of the southern Levant in the early Pleistocene was very similar to that of East Africa, implying that many taxa would not have had to adapt or change in any way to survive outside the African continent at this time. In Israel, the early Pleistocene fauna from Bethlehem includes Homotherium (a large sabre-toothed cat); a suid Sus cf. strozzi; a giraffid Giraffa cf. camelopardalis; a bovid Leptobos; a rhinoceros Dicerorhinus etruscus; Hipparion (three-toed horse); and a primitive elephant Elephas planifrons (Bar-Yosef 1994). These were generally open-country species, indicating an environment similar to an African lowland savanna. The absence of Equus, cervids, and other palearctic species could result from the Zagros-Caucasus mountain chain preventing the southward movement of fauna (Tchernov 1992), but other sites exhibiting the same faunal pattern need to be recovered before this hypothesis can be justified. (As seen below, for example, it is likely that Equus was present in Arabia at this time.) The slightly later and better known site of 'Ubeidiya, dated to c. 1.4 mya (Tchernov 1987), shows a more open-country, semi-arid environment, and is in agreement with the floral evidence for a gradual increase in aridity from the late Pliocene onward.

\section{Arabia, Turkey, and Iran}

Evidence that the Arabian peninsula was considerably less arid in the late Pliocene and early Pleistocene comes from the Wadi Birk, which was part of a river system that originally covered the whole Arabian Shelf and terminated in a delta fan with a radius of over $150 \mathrm{~km}$. Potassium-argon dating of basalt outcrops that were the source of gravels in the fan show that it was formed between 3.5 and 1.1 mya; the older basalt also showed lateritic weathering that can only occur under tropical, humid conditions (Hötzl and Zötl 1978). Further evidence for moister conditions during the early Pleistocene comes from three fossil localities in the An Nafud Desert in northwestern Saudi Arabia (Thomas et al. 1998). The remains have been recovered from lacustrine deposits found in interdune depressions, and include Crocuta crocuta (a hyena); Panthera of. gombaszoegensis (a large cat); Vulpes cf. vulpes (fox); an elephant, probably Elephas recki; Equus, possibly Hexaprotodon sp. (a hippopotamus-like animal); Pelorovis of. oldowayensis (a bovid); Oryx; and various types of alcelephines, bovids, and camelids. Fish and turtle are also present, indicating areas of perennial open water. Carbonate analyses of herbivore teeth indicate a diet of $\mathrm{C} 4$ plants typical of open grassland.

Moving further east, it is likely that the Tauros-Zagros mountains were already formed by the late Pliocene, and would already have been an impediment (but hardly a barrier) to animal and plant migration. Paleoenvironmental data from these areas are scarce, but it is worth noting evidence for a vast, shallow late Pliocene lake in the Kashafrud Basin in northeastern Iran. Stone artifacts have also been recovered in the vicinity, but their age is unknown (Arai and Thibault 1975/1977; Smith 1986). Similar evidence of early Pleistocene lakes comes from the Lake Eğirdir area of Anatolia, where terra rossa soils indicative of warm temperate to subtropical climatic conditions with both humid and dry seasons are found (Nemec and Kazanci 1999). 


\section{The Caucasus}

The Caucasus is unusual in that it has undergone its own history of uplift in the early Pleistocene, with the eastern flanks of the Greater Caucasus uplifted at an average rate of $0.6 \mathrm{~mm} \mathrm{yr}^{(-1)}$, and the Lesser Caucasus at a slower average rate of $0.3 \mathrm{~mm} \mathrm{yr}^{(-1)}$ for the past million years (Mitchell and Westaway 1999). The bestknown early Pleistocene site from this region is, of course, Dmanisi. Paleoenvironmental reconstructions of the region around Dmanisi indicate a semi-arid to warm Mediterranean type of climate, with many local water resources and a fairly open landscape with forests on riverbanks and mountain slopes (Gabunia et al. $2000 \mathrm{a}$ ). At the time of occupation, the site was only $60 \mathrm{~km}$ from the Caspian, which then joined the Black Sea (Gabunia et al. 2000b) and prevented dispersal further north, although Mitchell and Westaway (1999:182) argue that this did not occur until 1.2 mya. Several large carnivores - including the large sabre-tooth cats Megantereon megantereon and Homotherium crenatidens, another large felid Panthera gombaszoegensis, and a large hyena Pachycrocuta perrieri-mirror the habitat diversity surrounding the site. Pollen analysis indicates increasing aridity after the hominid occupation, leading to the expansion of steppe at the expense of forest habitats (Gabunia et al. 2000b). Akhalkalaki, another lower Pleistocene locality in Georgia, shows a moderately hot and dry climate with predominantly steppe vegetation and an Asiatic fauna including Crocuta (hyena), panther, and tiger (Vekua 1986). The same picture can also be seen in Central Asia. As can be observed from the loess and paleosol formations of Central Asia, as well as the faunal and floral remains, the late Pliocene climate was relatively wet and warm. The fauna was dominated by open landscape types including savanna animals, although some taxa from forest biozones have also been recovered. Precipitation was high enough in the Pliocene and early Pleistocene for a widespread forest zone to develop in the piedmont area of the Pamirs and southern Tien Shan (Dodonov et al. 1999). The extensive desert areas visible today had apparently not yet developed.

\section{Northern India and Pakistan}

The late Pliocene and early Pleistocene of northern Pakistan and India are represented by the Upper Siwaliks, or more specifically, the Pinjor Faunal Stage. This name derives from a locality near Chandigargh, India, although the Pinjor is best indicated in the Pabbi Hills (Dennell in press) and the Mangla-Samwal area (Hussain et al. 1992) of northern Pakistan. As elsewhere in southern Asia in the late Pliocene and early Pleistocene, conditions appear to have been generally moister than in later periods. The largest amount of dated vertebrate fossil material comes from the Pabbi Hills, where over 40,000 specimens (including indeterminates) have been collected, with roughly half from horizons between 1.8 and 2.2 mya and the rest from horizons 1.2-1.4 mya. The older horizons contain remains of Anthracotheres (extinct pig-like creatures); the giraffid Sivatherium giganteum; a very large bovid (type unknown); a small primate; and the large canid Canis cautleyi. The herbivores in this group were probably browsers, and their disappearance after 1.8 mya may indicate a contraction of woodland and the development of more arid conditions similar to that observed at Koobi Fora (Behrensmeyer et al. 1997). The fauna is otherwise dominated by grassland and 
open woodland types, notably Equus and Rhinoceros; a variety of medium-sized bovids; Gazella; Elephas; Stegodon; and ostrich. The main carnivores were Pachycrocuta (a giant hyena); followed by Megantereon (a sabre-tooth tiger); Panthera (leopard); and a small jackal-sized canid. Soil carbonate analyses (Quade et al. 1993) show an overwhelmingly C4 vegetation throughout the lower Pleistocene that is indicative of open grassland.

\section{South China and Southeast Asia}

The early Pleistocene environments of southern China, Southeast Asia, and Indonesia during the early Pleistocene are still poorly documented. According to Jablonski et al. (2000), a variety of sources (mostly soils and pollen) indicate that subtropical conditions prevailed over much of northern China, and tropical ones occurred south of the Qinling Mountains (see also Fig. 2). Studies of Javan biostratigraphy have been dominated by attempts to date the deposits from which hominids are known, or believed to have been derived, and less attention has been paid to paleoevironmental reconstructions. Recent work has tended to focus on confirming or refuting the $\mathrm{Ar}^{39} / \mathrm{Ar}^{40}$ dates obtained by Swisher et al. (1994) for the hominids from Sangiran and Mojokerto. In addition, the tectonic and volcanic stages by which the Indonesian archipelago was formed are highly complex, and further emphasize the distinctiveness of this landmass. Current work by Semah et al. (2000) suggests that the 'lower lahar,' a volcanic sediment layer at the base of deposits in the Sangiran Dome that marks the emergence of dry land in the area and as such circumscribes the first appearance of hominids, dates to c. 1.7 mya. This result is compatible with other recent $\mathrm{Ar}^{39} / \mathrm{Ar}^{40}$ dates obtained by Larick et al. (2001). They examined sediments from the SE quadrant of the Sangiran Dome where the Bapang (Kabuh) Formation has yielded almost $80 \mathrm{H}$. erectus specimens, over 50 of which have known find-spots (Larick et al. 2001). The dates range from $1.51 \pm 0.08$ mya at the Bapang/Sangiran Formation boundary to $1.02 \pm 0.06$ mya at the top of the hominid fossiliferous sequence. These results confirm the Swisher et al. claim (1994) that hominids were already there in the early Pleistocene (even though these claims are still contested; see, for example, Langbroek and Roebroeks 2000), and is also in keeping with van den Bergh et al.'s (2001) placement of the first Javan hominids in the Ci Saat fauna, that is, after 1.5 mya. Faunal evidence indicates open woodland and grassland, and includes animals such as Stegodon, Elephas, Rhinoceros, and suids. Dense rainforest did not appear until the Punung Stage, which is probably late Middle Pleistocene (Leinders et al. 1985). It needs to be borne in mind that even a $50 \mathrm{~m}$ drop in sea level during a cold period would have exposed Sundaland, a substantial coastal shelf linking Borneo, Sumatra, Java, and Malaysia (Tougard 2001:341), so that our knowledge of Early Pleistocene Indonesia is limited to only those parts that were above current sea levels. Additionally, there are no early Pleistocene palynological data that might provide a direct indication of past vegetation in this region.

\section{Implications}

Figure 2 summarizes the main environmental conditions that hominids would probably have encountered across southern Asia in the late Pliocene/early Pleis- 


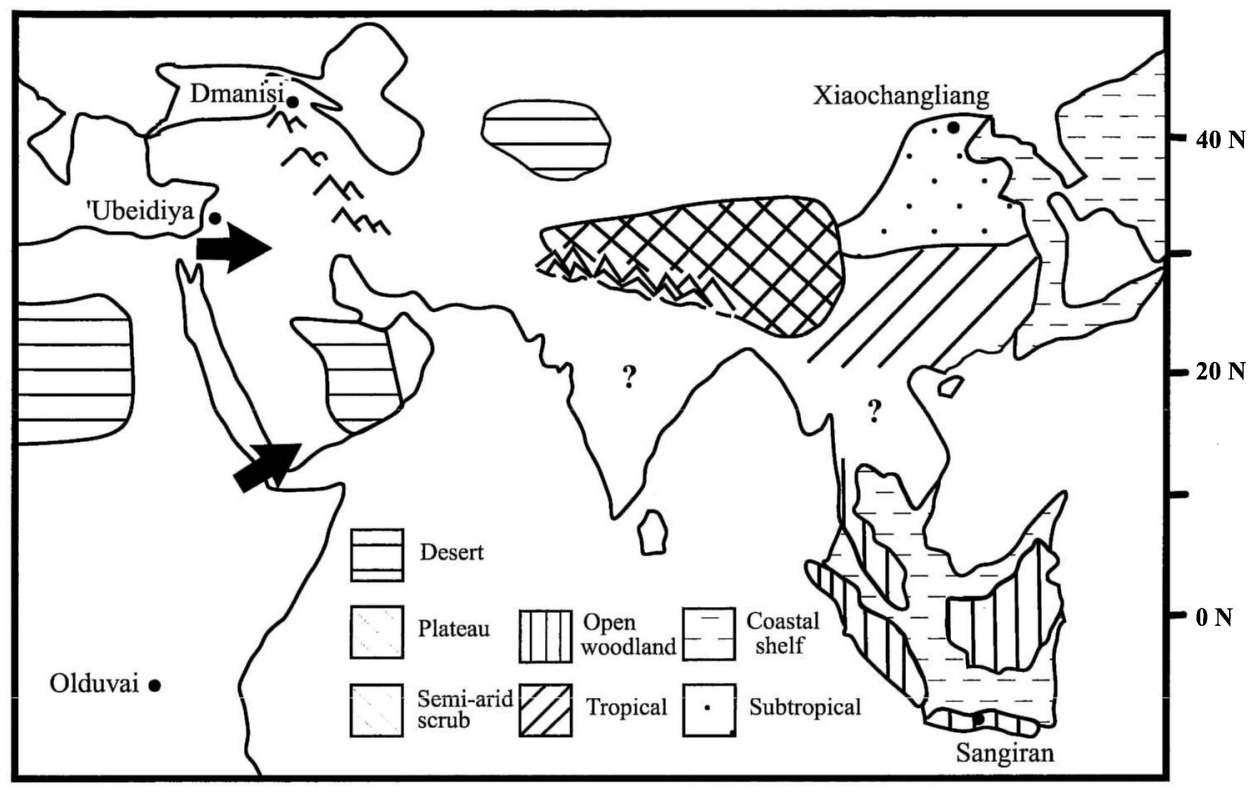

Fig. 2. Hominids and southern Asia during the Late Pliocene and Early Pleistocene (2.0-1.0 mya). Asia differed in key topographic respects from what it is today. The figure shows a conjoined Black and Caspian Sea north of Dmanisi, very limited desert cover in Arabia and Central Asia, and continuous grassland (shown in white) between Asia and Africa. Much of the Tibetan Plateau is assumed to have been at present elevations, but the Himalayan-Karakorum Mountains were generally lower than today. The boundary between tropical and subtropical vegetation in China probably extended to $30^{\circ} \mathrm{N}$, and there would have been a large coastal shelf off eastern China and across Indonesia at times of low sea level. Faunal data suggest that Java was open woodland at this time. Question marks over India and Southeast Asia indicate major areas of current uncertainty. It is suggested that hominids could have entered Asia from either the northern or southern end of the Red Sea, and then dispersed across Asian grasslands between 30 and $40^{\circ} \mathrm{N}$. The Himalayas and Tibetan Plateau would have confined hominids in South Asia to south of $25^{\circ} \mathrm{N}$. Dmanisi in Georgia and Xiaochangliang in North China may indicate the northernmost limit of hominids in warm periods. Sources: Dowsett et al. (1999) for the distribution of deserts and grasslands; Gabunia et al. (2000a) for the Black and Caspian Sea shorelines (NB: Mitchell and Westaway [1999] date the maximum expansion of this sea to 1.2 mya); Jablonski et al. (2000) for the paleocoastline of China at times of low sea level and the tropical/subtropical boundary; and van den Bergh et al. (2001) for the paleocoastline of Indonesia at times of low sea level.

tocene, c. 2 mya. In general terms, conditions in northeastern Africa and southwestern Asia were considerably moister than at present. Grasslands were prevalent across much of southern Asia, probably grading into open woodland in Southeast Asia. Both the loess and deep-sea records indicate numerous, but low amplitude, climatic fluctuations at this time with a periodicity of c. 41 kya. Consequently, latitudinal shifts in vegetation and fauna are likely to have been moderate between southern and central Asia. Overall, hominids would have encountered essentially the same conditions as in East Africa, and their presence across southern Asia c. 2.0-1.5 mya can be regarded as simply a latitudinal dispersion into the type of habitats they already utilized in East Africa.

If, as suggested, grasslands and a moister regime prevailed right across South Asia from Saudi Arabia to India, and northward to Central Asia and north-central China, and if the Red Sea and Nile were less effective faunal barriers than now, 
there would have been little impediment to hominids extending their range eastward across southern Asia-apart from the Zagros Mountains in Iran. Current data are insufficient to establish the full extent of hominids in the Asian grasslands at this time. However, we might note that late Pliocene australopithecines are assumed to have been endemic to the African grasslands on a continental scale (Brunet et al. 1995), and so we might cautiously assume that Homo was similarly ubiquitous throughout the southern Asian grasslands in the early Pleistocene. Indeed, we should not exclude the possibility that they may have been resident in Asia at an even earlier date. Dennell (1998) and Turner (1999) have both suggested, for example, that hominids might first have appeared in southern Asia in the late Pliocene well before 2 mya, when conditions were more favorable than later. Overall, the current scant evidence is best interpreted as a latitudinal extension of hominids by 1.8 mya across southwestern and southern Asia into grasslands south of c. $40^{\circ} \mathrm{N}$ in west Asia (with Dmanisi at $41^{\circ} \mathrm{N}$ in an unusually warm cul-de-sac and currently the most northerly acceptable piece of evidence) and perhaps further eastward. How much further east remains uncertain. Following Bar-Yosef and Belfer-Cohen (2001:22), claims from China for the presence of hominids at Dongyaozitou, Longgupo, and Renzidong, dating to 1.5 mya or earlier, are regarded as not proven. However, Zhu et al. (2001) have recently dated the hominid occupation at Xiaochangliang in the Nihewan Basin, North China $\left(40^{\circ} \mathrm{N}\right)$, to 1.36 mya - thus making it the oldest so far recognized in East Asia, as well as the earliest occupation this far north. Although few paleoclimatic data are provided, the faunal remains include Cervus and Gazella, which do not imply cold conditions. The artifacts were found in a greyish-white clay in a unit of silts and clay. The only loess present in the profile is from the last glaciation, and this might imply that conditions here were not excessively harsh during the Early Pleistocene. Unfortunately, it is not yet clear whether the occupation occurred during an interglacial or glacial period. Given the evidence from Gongwangling as well as Central Asia (see below), it seems likely that the occupation at Xiaochangliang was during a warm episode. The Javan evidence also indicates that hominids may have reached Indonesia before 1.5 mya, even if most are dated somewhat later. Despite what appears to have been a very extensive distribution of hominids across Asia in the Early Pleistocene, it is probable that hominid populations were discontinuous for much of the time, especially across the TaurosZagros arc between eastern Turkey and Iran.

\section{THE MIDDLE PLEISTOCENE}

Middle Pleistocene Asia was very different from its early Pleistocene counterpart, particularly because global climate was by then totally dominated by orbital factors. In particular, there was a shift toward low-frequency, high-amplitude alternations of glacial/interglacial climate (see Fig. 3) occurring on a cycle of $100 \mathrm{kya}$ instead of $41 \mathrm{kya}$ (Liu et al. 1999). Several ways in which changes in global ice volume dominated Asian climate are shown, in addition to the close similarity of oceanic and loess records, currently our best sources of data. After $800 \mathrm{kya}$, the Arctic Ocean was frozen year-round instead of seasonally (Herman and Hopkins 1980), thus further cooling Siberia. In Siberia, the biogenic silica record from Lake Baikal matches the marine oxygen isotope record throughout the last 800 


\section{Early Pleistocene}

\section{Cold}

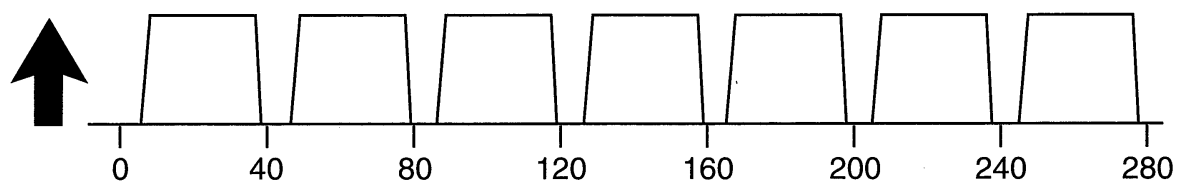

\section{Middle Pleistocene}

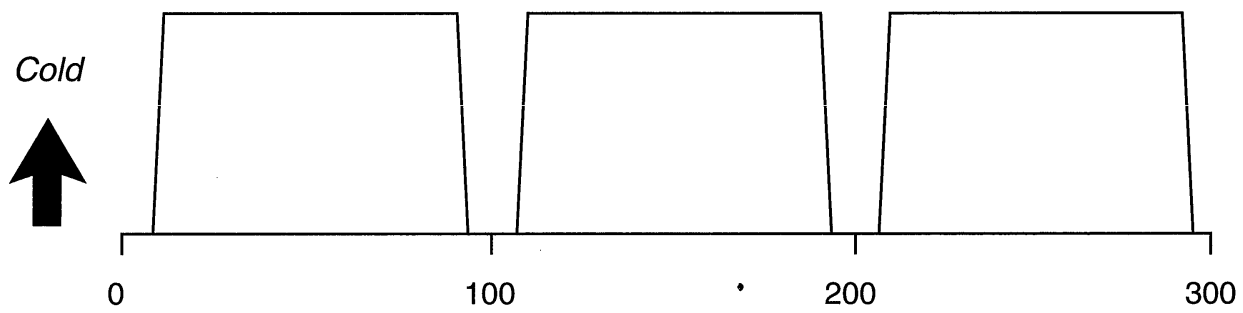

Fig. 3. Strength and frequency of Pleistocene glaciations. The figure summarizes the major contrasts between glaciations in the Early and Middle Pleistocene, between 1.8 and 0.5 mya (the vertical axis is not to scale and shows temperature in relative terms). (a) Early Pleistocene: glaciations were generally of low amplitude but high frequency, in other words, moderately severe and occuring approximately every 41,000 years. (b) Middle Pleistocene: glaciations after 800,000 years ago were high amplitude but low frequency; in other words, much more severe, longer-lasting, and occuring every 100,000 years.

kya (Prokopenko et al. 2001). At Baoji, Central China, Xiao and An (1999) document the strengthening of the East Asian monsoon, with greater and increasing contrasts between summer and winter monsoons beginning by 1.2-1.1 mya, as indicated by loess deposition in the lower Yangtze after 450 kya and in Lake Biwa, Japan. Ding et al. (1995) argue from studying loess sections at Baoji and Weinan on the Chinese loess plateau that the East Asian monsoon after 800 kya was driven primarily by ice-volume changes, although regionally, reduced vegetation and higher albedo over Central Asia would have further cooled the winds blowing south from Siberia. Sun et al. (1999) indicate that the East Asian monsoon would have forced the contraction and expansion of the deserts of northern China. Chen et al. (1999) show that in the Zoige Basin of eastern Tibet, climatic changes there were driven by ice volume changes, particularly after 500 kya. Offshore, marine pollen from the northwest Pacific shows the clear linkage of the East Asian monsoon to solar radiation changes (Heusser and Morley 1997). Even in the Arabian Sea, greater snow cover over Central Asia during glaciations would have lengthened and possibly cooled the northeast monsoon seasons off northeast Africa (Emeis et al. 1995). In other words, the data now emerging all suggest that the combined effects resulted in a continentally integrated weather system that 
intensified the aridification of southwestern Asia, made northern and Central Asia colder and drier, and reduced the monsoon in South and East Asia throughout most of the Middle Pleistocene.

There were additional, and often substantial, tectonic changes. Mineralogical analysis of sediments washed into the Bay of Bengal indicates a second rapid phase of Himalayan uplift after only 0.9 mya (Amano and Taira 1992). The fastest uplift rates were in the Nanga Parbat region of the Karakorum Mountains of Pakistan, where rates may have attained $0.7-1.5 \mathrm{~mm} \mathrm{yr}^{-1}$ (Zeitler et al. 1982). As a further example, the 3000-4000-m-high Pir Panjal Range that forms the flank of the "Outer Himalayas" is largely the product of only the last million years (Burbank and Johnson 1982). Further uplift seems also to have affected the north and east parts of the Tibetan Plateau (Sun and Liu 2000; Wu et al. 2001), while further east, the Qinling Mountains were probably uplifted by $1000 \mathrm{~m}$ during the Lower Pleistocene (Wang et al. 1997:229). Even more spectacularly, the Yangtze River may have formed in only the last million years (Huang 2001).

The importance of these tectonic changes beyond a regional level is uncertain. Some Chinese authors (e.g., Sun and Liu 2000) argue that Tibetan uplift would have further integrated linkage between loess deposition, monsoon circulation, and global ice volume changes. Indeed, Kukla and Cilek (1996:172) assert that, "the uplift of the Tibetan Plateau significantly contributed to the gradual climate deterioration of the last million years," thus clearly implying the direct influence of this uplift on global climate throughout the entire duration of the Asian hominid record. Himalayan uplift would certainly have blocked the Indian monsoon from entering Tibet, and may have intensified the monsoon over northern India, but is unlikely to have drastically altered climate elsewhere. However, it is likely that by the late Lower Pleistocene a strengthened Hadley cell drawing moist air northward from the Indian Ocean toward the Himalayas, but very dry air southward across Central Asia and toward Iran and Arabia, would have led to increased desertification in Southwest Asia.

Other Middle Pleistocene changes can be noted. One is that glacial-interglacial contrasts are likely to have been much greater, creating more pronounced latitudinal shifts in vegetation and climate. This effect would have been most marked in the increasingly arid parts of Southwest and Central Asia. We also note three likely faunal consequences during the Asian Middle Pleistocene. The first is the increasing degree of endemism in the faunas of the Indian subcontinent and Southeast Asia, including increased divergence from the African fauna. The second is the fragmenting of the distribution of some animals such as tiger, lion, leopard, rhinoceros, and elephant into island populations across Asia. This trend may have had the strongest impacts on large animals and solitary predators. Thirdly, there is some evidence for increased speciation in Southeast Asianotably the radiation of Asian macaques that appears, from genetic evidence, to be recent, and probably Middle Pleistocene in origin (Delson 1980).

\section{Archaeological Evidence for Hominids in Early Middle Pleistocene Asia}

Figure 4 summarizes the dominant features of a glacial Middle Pleistocene Asia that was dominated by low-frequency, high-amplitude climatic change characterized by major latitudinal differences between glacials and interglacials and an 


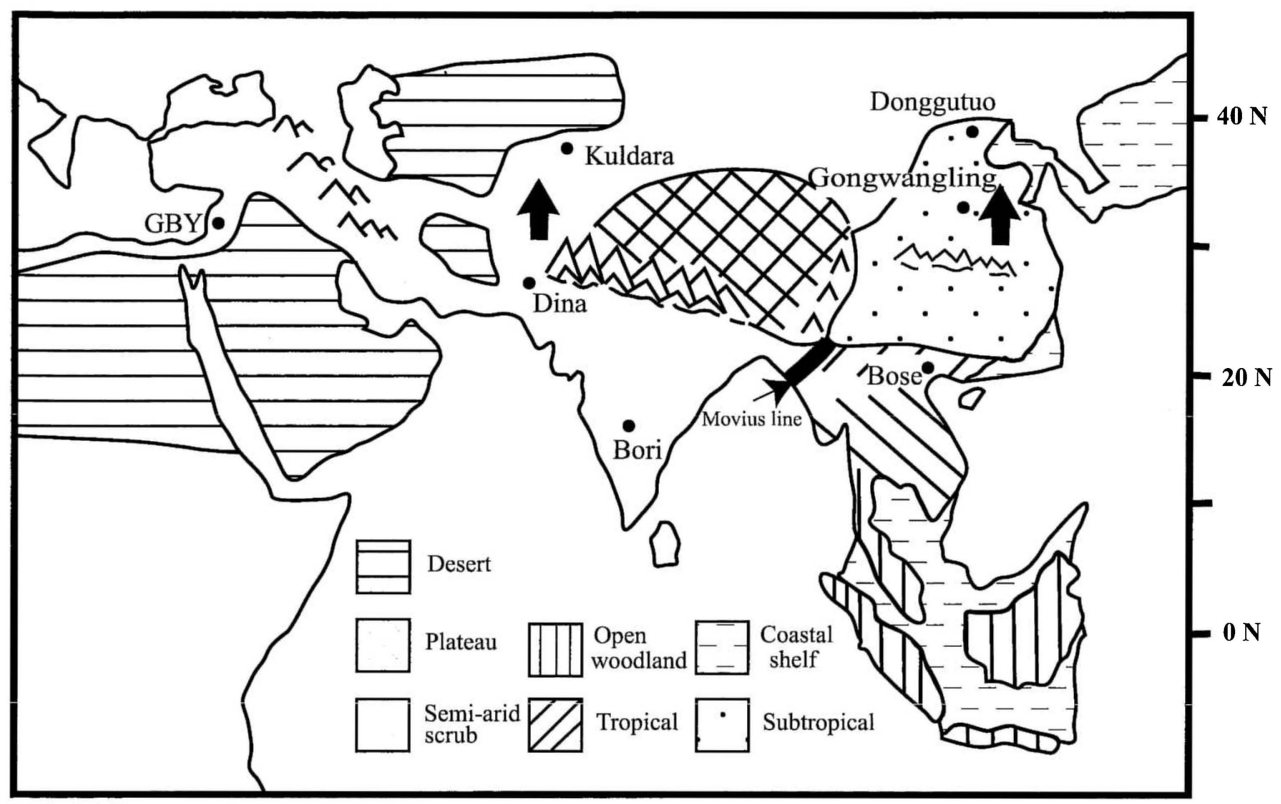

Fig. 4. Hominids and southern Asia between 1.0 and 0.5 mya. The figure indicates that extensive desert now prevailed across Arabia and the northern Sahara, as well as Central Asia and Iran. Additional and substantial mountain uplift by the Middle Pleistocene is indicated in the HimalayasKarakorum and also the Qinling Mountains of southern China. Tropical rainforest in China was displaced c. $10^{\circ} \mathrm{S}$ of its Early Pleistocene range. The Movius line (shown as a thick black line east of India) indicates the easternmost limit of Acheulean, bifacial industries, notwithstanding the new discovery at Bose, South China. It is suggested that under these increasingly severe conditions, hominids were still largely confined to south of $40^{\circ} \mathrm{N}$, except in interglacial periods, when they were able to disperse into Central Asia and northern China. Sources: Dowsett et al. (1999) for the distribution of deserts and grasslands; Jablonski et al. (2000) for the paleocoastline of China at times of low sea level and the tropical/subtropical boundary; and van den Bergh et al. (2001) for the paleocoastline of Indonesia at times of low sea level.

increasingly arid Southwest Asia. With this in mind, we can consider the Asian evidence for hominid occupation during the late Lower and early Middle Pleistocene (1.0-0.5 mya). This record is still extremely poor, as many regions are virtually uncharted, but enough seems outlined to identify two major developments during this period.

The Acheulean - The first major development is the appearance of Acheulean, bifacial assemblages in Southwest Asia and the Indian subcontinent. The dating of these is still imperfect. The oldest assemblages are in Israel, where the earliest Acheulean outside Africa occurs at 'Ubeidiya at c. 1.4 mya (Tchernov 1987), and sites like Gesher Benot Ya'acov at 0.8 mya (Goren-Inbar et al. 2000). There are no other absolute dates for the early Acheulean between Israel and Pakistan. There, hand axes have been found at Dina and Jalalpur in contexts dated paleomagnetically to c. 700-400 kya (Rendell and Dennell 1985). The appearance of the Acheulean may be further constrained in Pakistan by its absence in the Pabbi Hills before 1.2 and probably 0.9 mya (Hurcombe and Dennell 1993). In India, 
the earliest Acheulean dates are c. 670 kya from Bori $\left(18^{\circ} \mathrm{N}\right)$ (Mishra et al. 1995), but are likely to be older, given new evidence from Bose, South China. There, hand axes have been found that are associated with tektites that are dated to 800 kya (Hou et al. 2000). (The dating is problematic, however. Tektites are present over a very large area of Southeast Asia, but typically in much younger lag deposits resulting from denudation [Fiske et al. 1996, 1999; Koeberl and Glass 2000]. The age of the Bose artifacts therefore requires independent corroboration.) This major discovery may represent a short, atypical dispersal event from areas further west related to, and possibly immediately following, widespread forest-burning after the great Southeast Asian tektite shower that may date the assemblage (Hou et al. 2000). Even Bose, however, does not greatly alter the long-observed restriction of the Asian Acheulean to Southwest Asia and the Indian subcontinent.

An important point to stress is that the Asian Acheulean is largely confined to southern and Southwest Asia south of $35^{\circ} \mathrm{N}$, that is, within the area first occupied in the Lower Pleistocene. (Its northernmost limits remain unclear, and depend partly upon definitions of "Acheulean"; nevertheless, it may make a late Middle Pleistocene appearance in Central Asia, as at Sel'oungour, Uzbekistan [Islamov 1990].) There is no need to posit an immigrant population from Africa, as the conventions for this type of flaking could have resulted from diffusion; but as noted earlier, populations may also have been intermittent, especially in Southwest Asia during very arid phases of glaciations. The Acheulean in Asia does appear to be restricted to open grasslands. East of the "Movius line" in the woodlands and forests of Southeast Asia these bifaces appear to have been unnecessary, possibly because bamboo and other woods could have fulfilled the same function (Pope 1989) or possibly because of greater reliance on plant foods (Watanabe 1985). As Schick (1994) has pointed out, the complex rules of manufacture also made the Acheulean vulnerable to discontinuities in space and time. If, as suggested earlier, populations across Asia in the Lower and Middle Pleistocene were vulnerable to environmental displacement and disruption, it may also be that more flexible and informal methods of stone tool manufacture were more appropriate in eastern Asia.

Hominid Dispersals into Cooler Environments - The second trend apparent in the late Lower Pleistocene is the evidence for hominids in cooler environments across Europe and Central and East Asia as far north as $40-45^{\circ} \mathrm{N}$ (as noted previously, Southwest Asia is slightly aberrant, because of the existence of a joint BlackCaspian Sea in the late Pliocene and early Pleistocene). Precisely when hominids began to occupy, even if intermittently, this vast area of northerly temperate latitudes is still unclear because the number of well-dated sites is so small. Until very recently, it seemed that this process began around one million years ago. To take a continental transect across Eurasia, the earliest current dates in these latitudes are from the Orce Basin, Spain $\left(38^{\circ} \mathrm{N}\right)$ at c. 1 mya (Oms et al. 2000); Atapuerca TD6, Spain $\left(42^{\circ} \mathrm{N}\right)$ at c. 780 kya (Carbonell et al. 1995); Kuldara, Tadjikistan $\left(38^{\circ} \mathrm{N}\right)$ at $900 \mathrm{kya}$ (Ranov 1995); and Donggutuo in North China $\left(40^{\circ} \mathrm{N}\right)$ at 0.9 mya (Jia and Wei 1987). None of these assemblages is Acheulean. They are usually regarded as Mode 1 or simple flake and core assemblages. Given the scale of environmental fluctuations that are likely to have occurred across Central and 
Southwest Asia during this period, there is no reason to assume that these northward dispersions of hominids imply permanent colonization. Instead, hominid usage of these latitudes in the late Lower Pleistocene and early Middle Pleistocene is likely to have been intermittent and geographically discontinuous, in much the same way as suggested for Europe at this time (Roebroeks 2001). It is also probable that these forays into more northerly areas were initially confined to interglacials. In Central Asia, for example, sites such as Kuldara (and later ones such as Lakatui and Karatau) are found only in paleosols indicating interglacials (Dodonov and Baiguzina 1995:712). Also, Wang et al. (1997) suggest that the first hominids at Gongwangling, north of the Qinling Mountains (34 $\left.{ }^{\circ} \mathrm{N}\right)$ c. 1.15 mya, were only there in warm seasons. It is only after 650 kya (at Chenjiawo) that they are found in both cold and warm periods, as is the case in Europe after 500 kya (see Gamble 1999:107).

\section{CONCLUSIONS}

Various conclusions are drawn from this overview of Asian biogeography regarding hominid dispersals. First, dispersions of hominids across the grasslands of southern Asia may have begun before 2 mya. Those dispersions indicated between 2 and 1.5 mya can be regarded as a latitudinal extension of the hominid range eastward from Africa, up to but not beyond $30^{\circ} \mathrm{N}$. There is no reason to suppose that these dispersals resulted in the permanent, continuous colonization of the South Asian landmass. Secondly, the dominant event between 1.0 and 0.5 mya (or more precisely, ca. 0.8 mya) was a strengthening of the monsoon in the Indian subcontinent and Southeast Asia that combined with increased aridity in Southwest Asia to create the current desert barrier between East Africa and South Asia. This may have been reinforced (but not caused) by the continuing uplift of the Himalayas-Karakorum and the Tibetan Plateau. Against a background of global cooling, these regional effects are likely also to have resulted in much greater latitudinal shifts in climate and vegetation between glacial and interglacial conditions, particularly across Southwest and Central Asia. Given these regional effects, if anatomically modern humans from Africa did displace indigenous populations of East and Southeast Asian hominids between 100 and 60 kya (when conditions were glacial), they would have encountered extremely formidable environmental barriers, including many areas that were probably uninhabitable with the prevailing technologies and social strategies.

The extension of Acheulean bifacial toolkits across Southwest and South Asia (within the area already occupied in the Lower Pleistocene) between 1.4 and 0.8 mya occurred against this background of increasing aridity. This need not imply immigrant populations of African hominids. Population movement was probably mostly confined to the numerous warmer, wetter episodes every 40 kya or so. Northward dispersals between 35 and $45^{\circ} \mathrm{N}$ into Central Asia and northern China (and also Western Europe) may be linked to increased encephalization in hominids by this time, and their greater abilities to cope with environmental stress. Such stresses would have been greatest during winter when resources, usable daylight, and temperatures were at a minimum. More controlled use of fire (James 1989) and improved hunting techniques, including the use of spears (e.g., Thieme 1997), may also have been important developments. Even so, before 
$500 \mathrm{kya}$ in Europe, but perhaps somewhat earlier in eastern Asia, these dispersals northward appear to have been intermittent episodes, confined to interglacial periods. Certainly, it is premature to write artifact-based culture histories prior to 500 kya in Asia that assume continuous occupation. Finally, the continental-level trends reviewed in this paper emphasize the importance of regional Asian specialists sharing a broad perspective of how changes in one part of Asia could radically affect conditions elsewhere.

\section{ACKNOWLEDGEMENTS}

I am grateful to Sari Miller-Antonio and Lynne Schepartz for organizing such an excellent conference in Honolulu; to Katherine Holmes for drawing my attention to some of the references and material cited in this article, particularly on Southwest Asia; and to Marco Langbroek for drawing my attention to the problem of dating tektites. Thanks also to Linda Hurcombe for critical comment on the text. Needless to say, errors of fact and interpretation are entirely mine.

\section{REFERENCES CITED}

Amano, Kazuo, and Asahiko Taira

1992 Two-phase uplift of Higher Himalayas since 17 Mya. Geology 20:391-394.

An Zhisheng, John E. Kutzbach, Warren L. Prell, and Stephen C. Porter

2001 Evolution of Asian monsoons and phased uplift of the Himalaya-Tibetan plateau since Late Miocene times. Nature 411:62-66.

Arai, A., AND C. Thibault

1975/ Nouvelles précisions à propos de l'outillage paléolithique ancien sur galets du Khorassan 1977 (Iran). Paléorient 3:101-108.

BAR-YOSEF, OFER

1994 The lower palaeolithic of the Near East. Journal of World Prehistory 8(3):211-265.

BAR-Yosef, Ofer, AND A. Belfer-Cohen

2001 From Africa to Eurasia-early dispersals. Quaternary International 75 : 19-28.

Behrensmeyer, Anna K., Nancy E. Todd, Richard Potts, and Geraldine E. McBrinn

1997 Late Pliocene faunal turnover in the Turkana Basin, Kenya and Ethiopia. Science 278:1589-1594.

Blisnuik, Peter M., Bradley R. Hacker, Johannes Glodny, Lothar Ratschbacher, Bi Siwen, Wu Zhenhuan, Michael O. McWilliams, and Andy Calvert

2001 Normal faulting in central Tibet since at least 13.5 Myr ago. Nature 412:629-632.

Brunet, Michel, Alain Beauvillain, Yves Coppens, Émile Heintz, Aladji H. Moutaye, and David Pilbeam

1995 The first australopithecine 2500 kilometres west of the Rift Valley (Chad). Nature $378: 273-274$.

Burbank, Douglas W., and Gary D. Johnson

1982 Intermontane-basin development in the past 4 Myr in the north-west Himalaya. Nature $298: 432-436$.

Burbank, Douglas W., and Robert G. H. Reynolds

1984 Sequential late Cenozoic disruption of the northern Himalayan foredeep. Nature 311:114-118.

Busche, D.

2001 Early Quaternary landslides of the Sahara and their significance for geomorphic and climatic history. Journal of Arid Environments 49:429-448.

Butzer, Karl W., and Carl L. Hansen

1968 Desert and River in Nubia: Geomorphology and Prehistoric Environments at the Aswan Reservoir. Madison: University of Wisconsin Press. 
Cane, Mark A., and Peter Molnar

2001 Closing of the Indonesian sea-way as a precursor to east African aridification around 3-4 million years ago. Nature $411: 157-162$.

Carbonell, Eudald, J. M. Bermudez de Castro, J. L. Arsuaga, J. C. Díez, A. Rosas, G. Cuenca-Bescós, R. Sala, M. Mosquera, and X. P. Rodríguez

1995 Lower Pleistocene hominids and artifacts from Atapuerca-TD6 (Spain). Science 269:826829.

Chen, F. H., J. Bloemendal, P. Z. Zhang, and G. X. Liu

1999 An 800 ky proxy record of climate from lake sediments of the Zoige Basin, eastern Tibetan Plateau. Palaeogeography, Palaeoclimatology and Palaeoecology 151(4):307-320.

Coleman, Margaret, and Kip Hodges

1995 Evidence for Tibetan plateau uplift before 14 Myr ago from a new minimum age for eastwest extension. Nature 374:49-52.

Davis, Richard S.

1987 Regional perspectives on the Soviet Central Asian palaeolithic, in The Pleistocene Old World: Regional Perspectives: 121-133, ed. Olga Soffer. New York and London: Plenum Press.

DeLson, Eric

1980 Fossil macaques, phyletic relationships and a scenario of deployment, in The Macaques: Studies in Ecology, Behavior and Evolution: 10-29, ed. D. G. Lindburg. New York: Van Nostrand Reinhold Co.

Dennell, Robin W.

1983 European Economic Prehistory: A New Approach. London and New York: Academic Press.

1998 Grasslands, tool-making and the earliest colonization of south Asia: a reconsideration, in Early Human Behavior in Global Context: The Rise and Diversity of the Lower Palaeolithic Record: 280-303, ed. Michael Petraglia and Ravi Korisettar. London: Routledge.

2004 Early Hominin Landscapes in Northern Pakistan: Investigations in the Pabbi Hills. British Archaeological Reports (International Series) $1265: 1-454$.

Dennell, Robin W., Helen R. Rendell, and Ernie Hailwood

1988 Early tool-making in Asia: two-million-year-old artefacts in Pakistan. Antiquity 62:98106.

Ding Zhongli, Liu Tungsheng, Nat W. Rutter, Yu Zhiwei, Guo Zhengtang, and Zhu

RIXIANG

1995 Ice-volume forcing of East Asian winter monsoon variations in the past 800,000 years. Quaternary Research 44:149-159.

Ding Zhongli, N. W. Rutter, J. M. Sun, S. K. Yang, and T. S. Liu

$2000 \mathrm{Re}$-arrangement of atmospheric circulation at about 2.6 Mya over northern China: evidence from grain size records of loess-palaeosol and red clay sequences. Quaternary Science Reviews 19(6): 547-558.

Ding Zhongli, S. F. Xiong, J. M. Sun, S. L. Yang, Z. Y. Gu, and T. S. Liu

1999 Pedostratigraphy and paleomagnetism of a $\sim 7.0$ Mya eolian loess-red clay sequence at Lingtai, Loess Plateau, north-central China and the implications for palaeomonsoon evolution. Palaeogeography, Palaeoclimatology and Palaeoecology 152(1-2):49-66.

Ding Zhongli, And S. L. Yang

2000 C3/C4 vegetation evolution over the last 7.0 Myr in the Chinese Loess Plateau: Evidence from pedogenic carbonate $\delta 13 \mathrm{C}$. Palaeogeography, Palaeoclimatology and Palaeoecology $160(3-4): 291-299$.

Dodonov, A. E., AND L. L. BAiguzinA

1995 Loess stratigraphy of Central Asia: Palaeoclimatic and palaeoenvironmental aspects. Quaternary Science Reviews 14:707-720.

Dodonov, A. E., N. J. Shackelton, L. P. Zhou, S. P. Lomov, and A. F. Finaev

1999 Quaternary loess-paleosol stratigraphy of Central Asia: geochronology, correlation and evolution of paleoenvironments. Stratigraphy and Geological Correlation 7(6):581-593.

Dowsett, Harry J., John A. Barron, Richard Z. Poore, Robert S. Thompson, Thomas M.

Cronin, Scott E. Ishman, and Debra A. Willard

1999 Middle Pliocene paleoenvironmental reconstruction: PRISM2 U.S. Geological Survey Open File Report: 99-535. 
Emeis, Kay-Christian, David M. Anderson, Heidi Doose, Dick Kroon, and Detlef Schulz-

BuLL

1995 Sea-surface temperatures and the history of monsoon upwelling in the Northwestern Arabian Sea during the last 500,000 years. Quaternary Research 43:355-361.

Fiske, P. S., C. C. Schnetzler, J. Mchone, K. K. Chanthya Vaitchith, I. Homsombath, T. Phouthakayalat, B. Khenthavong, and P. T. Xuan

1999 Layered tektites of southeast Asia: Field studies in central Laos and Vietnam. Meteoritics and Planetary Science $34: 757-761$.

Fiske, P. S., Putthapiban Wasson, and J. T. Wasson

1996 Excavation and analysis of layered tektites from northeast Thailand: results of 1994 field expedition. Meteoritics and Planetary Science 31:36-41.

Fort, MONIQUe

1996 Late Cenozoic environmental changes and uplift on the northern side of the central Himalaya: a reappraisal from field data. Palaeogeography, Palaeoclimatology and Palaeoecology $120: 123-145$.

Gabunia, Leo, Abesalom Vekua, and David Lordkipanidze

2000 The environmental contexts of early human occupation of Georgia (Transcaucasia). Journal of Human Evolution 38:785-802.

Gabunia, leo, Abesalom Vekua, David lordkipanidze, Carl C. Swisher iti, Reid Ferring, Antje Justus, Medea Nioradze, Merab Tvalchrelidze, Susan C. Antón, Gerhard Bosinski, Olaf Jöris, Marie-A. De Lumley, Givi Majsuradze, and Aleksander Mouskhelishvili

2000 Earliest Pleistocene hominid cranial remains from Dmanisi, Republic of Georgia: Taxonomy, geological setting, and age. Science 288:1019-1025.

Gamble, Clive

1995 Timewalkers: The Prehistory of Global Colonisation. Stroud: Alan Sutton.

1999 Palaeolithic Societies of Europe. Cambridge: Cambridge University Press.

Goren-Inbar, Naama, Craig S. Feibel, Kenneth L. Verosub, Yoel Melamed, Mordechai E.

Kislev, Eitan TChernov, and Idit Saragusti

2000 Pleistocene milestones on the Out-of-Africa corridor at Gesher Benot Ya'aqov, Israel. Science 289: 944-947.

Han, J., W. S. Fyfe, F. J. Longstaffe, H. C. Palmer, F. H. Yan, and X. S. Mai

1997 Pliocene-Pleistocene climatic change recorded in fluviolacustrine sediments in central China. Palaeogeography, Palaeoclimatology and Palaeoecology 135(1-4):27-39.

Herman, Yvonne, and David M. Hopkins

1980 Arctic Ocean in late Cenozoic time. Science 209:557-562.

Heusser, Linda, AND Joseph MORLEy

1997 Monsoon fluctuations over the past $350 \mathrm{Kyr}$ : high-resolution evidence from northeast Asia/northwest Pacific climate proxies (marine pollen and radiolarians). Quaternary Science Reviews 16(6): 565-581.

HötzL, H., AND J. G. ZÖTL

1978 Summary and general conclusions-climatic changes during the Quaternary period, in Quaternary Period in Saudi Arabia. Sedimentological, Hydrogeological, Hydrochemical and Climatological Investigations in Central and Eastern Saudi Arabia, ed. A. R. Jado and J. G. Zötl. Vienna and New York: Springer Verlag.

Hou Yamei, Richard Potts, Yuan Baoyin, Guo Zhengtang, Alan Deino, Wang Wei, Jennifer Clark, Xie Guangmao, and Huang Weiwen

2000 Mid-Pleistocene Acheulean-like stone technology of the Bose Basin, South China. Science 287 : 1622-1626.

HuANG WANPO

2001 The formation of the Three Gorges and the environmental changes in the Yangtze River region. Unpublished conference abstract, Asia and the Middle Pleistocene in Global Perspective. East-West Center, University of Hawai'i, March 14-17, 2001.

Huang Wanpo, Russell Ciochon, Gu Yumin, Roy Larick, Fang Qiren, Henry Schwarcz, Charles Yonge, John de Vos, and William Rink

1995 Early Homo and associated artefacts from Asia. Nature 378:275-278. 
Hurcombe, Linda, and R. W. Dennell

1993 A Pre-Acheulean in the Pabbi Hills, northern Pakistan?, in South Asian Archaeology 1989 (Proceedings of the International Conference of South Asian Archaeologists in Western Europe, Paris, July 1989): 133-136, ed. Catherine Jarrige. Madison: Prehistory Press.

Hussain, Taseer S., Gert D. van der Bergh, Karel J. Steensma, Johanna A. de Visser, John de Vos, Mohammad Arif, Jan van Dam, Paul Y. Sondaar, and Sikander B. Malik

1992 Biostratigraphy of the Plio-Pleistocene continental sediments (Upper Siwaliks) of the Mangla-Samwal Anticline, Azad Kashmir, Pakistan. Proceedings of the Koninklijke Nederlandse Akademie van Wetenschappen 95(1):65-80.

ISLAMOV, Y. I.

1990 Sel'oungour, un nouveau site du paléolithique inférieur en Asie Centrale. L'Anthropologie 94(4):675-688.

Jablonski, Nina G., Matthew J. Whitford, Nola Roberts-Smith, and Xu Qinqi

2000 The influence of life history and diet on the distribution of catarrhine primates during the Pleistocene in eastern Asia. Journal of Human Evolution 39(2) : 131-157.

JAMES, Stephen R.

1989 Hominid use of fire in the Lower and Middle Pleistocene. Current Anthropology 30(1): 126.

JiA LANPO, AND WEI QI

1987 Artefacts lithiques provenant du site pleistocene ancien de Donggutuo près de Nihewan (Nihowan), province d'Hebei, Chine. L'Anthropologie 91(3) : 727-732.

Koeberl, C., and B. P. Glass

2000 Tektites and the age paradox in Mid-Pleistocene China. Science 289:507a (electronic version only).

Kukla, George, and VÁClav Cílek

1996 Plio-Pleistocene megacycles: record of climate and tectonics. Palaeogeography, Palaeoclimatology and Palaeoecology 120(1-2): 171-194.

LANGBroek, Marco, and Wil Roebroeks

2000 Extraterrestrial evidence on the age of the hominids from Java. Journal of Human Evolution $38: 595-600$.

Larick, R., R. L. Ciochon, Y. Zaim, S. Suminto, Y. Izal, F. Aziz, M. Reagan, and M. Heizler 2001 Early Pleistocene Ar-40/Ar-39 ages for Bapang Formation hominins, Central Java, Indonesia. Proceedings of the National Academy of Sciences of the USA 98(9): 4866-4871.

Leinders, J.J.M., F. Aziz, Paul Y. SondaAr, and John de Vos

1985 The age of the hominid-bearing deposits of Java: State of the art. Geologie en Mijnbouw $64: 167-173$.

Lu Huayu, Liu Xiaodong, Zhang Fuqing, An Zhisheng, and John Dodson

1999 Astronomical calibration of loess-paleosol deposits at Luochan, central Chinese Loess Plateau. Palaeogeography, Palaeoclimatology and Palaeoecology 154(3): 237-246.

Mishra, S., T. R. Venkatesan, S. N. Rajaguru, and B.L.K. Somayajulu

1995 Earliest Acheulian industry from Peninsular India. Current Anthropology 36(5): 847-851.

Mitchell, John, and Rob Westaway

1999 Chronology of Neogene and Quaternary uplift and magmatism in the Caucasus: constraints from K-Ar dating of volcanism in Armenia. Tectonophysics 304:157-186.

NemeC, W., AND N. KazAnCi

1999 Quaternary colluvium in west-central Anatolia: sedimentary facies and palaeoclimatic significance. Sedimentology 46:139-170.

Oms, Oriol, J. M. Parés, B. Martínez-Navarro, J. Agustí, I. Toro, G. Martínez-Fernández, AND A. TURQ

2000 Early human occupation of western Europe: Paleomagnetic dates for two paleolithic sites in Spain. Proceedings of the National Academy of Sciences of the USA 97(19): 10666-10670.

Pope, Geoffrey C.

1983 Evidence on the age of the Asian hominidae. Proceedings of the National Academy of Sciences of the USA 80:4988-4992.

1989 Bamboo and human evolution. Natural History 98(10):49-57. 


\section{Prell, Warren L., and John E. Kutzbach}

1992 Sensitivity of the Indian monsoon to forcing parameters and implications for its evolution. Nature 360:647-651.

Prokopenko, Alexander A., Eugene B. Karabanov, Douglas F. Williams, Mikhail I. Kuzmin, Nicholas J. Shackleton, Simon J. Crowhurst, John A. Peck, Alexander N. Gvozdkov, and JOHN W. KING

2001 Biogenic silica record of the Lake Baikal response to climatic forcing during the Brunhes. Quaternary Research 55(2): 123-132.

Quade, Jay, and Thure E. Cerling

1995 Expansion of C4 grasses in the Late Miocene of northern Pakistan: evidence from stable isotopes in paleosols. Palaeogeography, Palaeoclimatology and Palaeoecology 115(1-4):91-116.

Quade, Jay, Thure E. Cerling, J. R. Bowman, and Asif Jah

1993 Paleoecologic reconstruction of floodplain environments using palaeosols from Upper Siwalik Group sediments, northern Pakistan, in Himalaya to the Sea: Geology, Geomorphology and the Quaternary: 213-226, ed. Jack F. Schroder. London and New York: Routledge.

RANOV, VADIM

1995 The 'Loessic Palaeolithic' in South Tadjikistan, Central Asia: Its industries, chronology and correlation. Quaternary Science Reviews 14:731-745.

Rendell, Helen M., and Robin W. Dennell

1985 Dated lower palaeolithic artefacts from northern Pakistan. Current Anthropology $26(5): 393$.

Roebroeks, WIL

2001 Hominid behaviour and the earliest occupation of Europe: An exploration. Journal of Human Evolution 41 : 437-461.

ROLLAND, NichOLAS

2001 The initial peopling of Eurasia and the early occupation of Europe in its Afro-Asian context: major issues and current perspectives, in A Very Remote Period Indeed: Papers on the Palaeolithic presented to Derek Roe: 78-94, ed. S. Milliken and J. Cook. Oxford: Oxbow Books Ltd.

Ronen, Avraham

1991 The Yiron-gravel lithic assemblage: artefacts older than 2.4 Mya in Israel. Archäologisches Korrespondenzblatt $21: 159-164$.

SCHICK, KATHY D.

1994 The Movius Line reconsidered: perspectives on the Earlier Paleolithic of Eastern Asia, in Integrative Paths to the Past: Paleoanthropological Advances in Honor of F. Clark Howell: 569-594, ed. R. Corruchini and R. Ciochon. New Jersey: Prentice Hall.

Schwartz, JefFrey H., and Ian Tattersall

1996 Whose teeth? Nature 381:201-202.

Semah, François, Hassane Saleki, Christophe Falguères, Gilbert Féraud, and Tony Djubiantono

2000 Did early man reach Java during the Late Pliocene? Journal of Archaeological Science $27: 763-769$.

Shackleton, Nicholas J., J. Backman, H. Zimmerman, D. V. Kent, M. A. Hall, D. G. Roberts, D. Schitker, J. Baldauf, A. Despaires, R. Homrighausen, P. Huddlestun, J. Keene, A. J.

Kaltenback, K. A. Krumsiek, A. C. Morton, J. W. Murray, and J. Westberg-Smith

1984 Oxygen isotope calibration of the onset of ice-rafting and history of glaciation in the North Atlantic region. Nature 307:620-623.

Shi N., J. X. CaO, and L. K. Konigsson

1993 Late Cenozoic vegetational history and the Plio-Pleistocene boundary in the Yuse Basin, SE Shanxi Province, China. Grana 32(4-5):260-271.

Smith, Phillip E.

1986 Palaeolithic Archaeology in Iran. Philadelphia: University Museum.

Stringer, Chris B., AND R. McKie

1996 African Exodus: The Origins of Modern Humanity. London: Jonathan Cape. 
Sun C. J., Ding Zhongli, Liu Tungsheng, D. Rokosh, and Nat Rutter

1999 580,000-year environmental reconstruction from aeolian deposits at the Mu Us desert margin. Quaternary Science Reviews 18(12): 1351-1364.

Sun Jimin AND Liu Tungsheng

2000 Stratigraphic evidence for the uplift of the Tibetan Plateau between $\sim 1.1$ and $\sim 0.9 \mathrm{Myr}$ ago. Quaternary Research 54:309-320.

Swisher, Carl C. III, G. H. Curtis, T. Jacob, A. G. Getty, A. Suprijo, and Widiasmoro

1994 Age of the earliest known hominids in Java Indonesia. Science 263:1118-1121.

TATTERSALL, IAN

1997 Out of Africa again ... and again? Scientific American 276(4):46-53.

TCHERnOv, EITAN

1987 The age of the 'Ubeidiya Formation, an Early Pleistocene hominid site in the Jordan Valley, Israel. Israel Journal of Earth Sciences 36:3-30.

1992 Eurasian-African biotic exchanges through the Levantine corridor during the Neogene and Quaternary, in Mammalian Migration and Dispersal Events in the European Quaternary: 103-123, ed. W. von Koenigswald and Lars Werdelin. Courier Forschungsinstitut Senckenberg, Frankfurt.

Thieme, Hartmut

1997 Lower palaeolithic hunting spears from Germany. Nature 385 : 807-810.

Thomas, Herbert, Denis Geraads, Dominique Janjou, Denis Vaslet, Abdallah Memseh, Daniel Billiou, Hervé Bocherens, Gauthier Dobigny, Vera Eisenmann, V. Gayet, Mireille Lapparent de Broin, Germaine Petter, and Mohammed Halawani

1998 Découverte des premières faunes pléistocene de la péninsule Arabique dans le désert du Nafoud (Arabie Saoudite). Compte Rendu de l'Academie des Sciences, Paris 326:145-152.

Thorne, Alan G., and Milford H. Wolpoff

1992 The multiregional evolution of humans. Scientific American 266:28-33.

Tougard, C.

2001 Biogeography and migration routes of large mammals in South-East Asia during the Late Middle Pleistocene: focus on the fossil and extant faunas from Thailand. Palaeogeography, Palaeoclimatology and Palaeoecology 168(3-4):337-358.

Turner, Alan

1992 Large carnivores and earliest European hominids: Changing determinants of resource availability during the Lower and Middle Pleistocene. Journal of Human Evolution 22:109-126.

1999 Assessing earliest human settlement of Eurasia: Late Pliocene dispersions from Africa. Antiquity 73:563-570.

van den Bergh, Gert D., Jon de Vos, and Paul Y. Sondaar

2001 The Late Quaternary palaeogeography of mammal evolution in the Indonesian Archipelago. Palaeogeography, Palaeoclimatology and Palaeoecology $171: 385-408$.

Vekua, Abesalom

1986 The lower Pleistocene mammalian fauna of Akhalkalaki (southern Georgia, USSR). Palaeontologica Italica $74: 63-96$.

Wang Hong, Stanley H. Ambrose, Liu Chao-Li Jack, and Leon R. Follmer

1997 Paleosol stable isotope evidence for early hominid occupation of East Asian temperate environments. Quaternary Research 48(2):228-238.

Wang Jian, Wang Yong Jin, Liu Ze Chun, Li Jian Qing, and Ping Xi

1999 Cenozoic environmental evolution of the Qaidam Basin and its implications for the uplift of the Tibetan Plateau and the drying of central Asia. Palaeogeography, Palaeoclimatology and Palaeoecology 152(1-2):37-47.

WATANABE, Hitoshi

1985 The chopper-chopping tool complex of eastern Asia: an ethnoarchaeological-ecological reexamination. Journal of Anthropological Archaeology 4:1-18.

Williams, D. F., J. Peck, E. B. Karabanov, A. A. Prokopenko, V. Kravchinsky, J. King, and M. I. KuzMin

1997 Lake Baikal record of continental climate response to orbital insolation during the past 5 million years. Science 278:1114-1117. 
Wu Yongqiu, Cui Zhijiu, Liu Gengnian, Ge Daokai, Yin Jiarun, Xu Qinghai, and Pang QIQING

2001 Quaternary geomorphological evolution of the Kunlun Pass area and uplift of the Qinghai-Xizang (Tibet) Plateau. Geomorphology 36(3-4) : 203-216.

Xiao Jule and An Zhisheng

1999 Three large shifts in East Asian monsoon circulation indicated by loess-paleosol sequences in China and late Cenozoic deposits in Japan. Palaeogeography, Palaeoclimatology and Palaeoecology 154(3): 179-189.

Zeitler, P. K., N. M. Johnson, C. W. Naeser, and R.A.K. Tahirkheli

1982 Fission-track evidence for Quaternary uplift of the Nanga Parbat region, Pakistan. Nature 298:255-257.

Zhu, R. X., K. A. Hoffman, R. Potts, C. L. Deng, Y. R. Pan, B. Guo, C. D. Shi, Z. T. Guo, Y. M. Hou, AND W. W. HuANG

2001 Earliest presence of humans in northeast Asia. Nature 413:413-417.

\begin{abstract}
This paper examines the environmental context of human dispersals into Asia up to 0.5 mya. These dispersals were probably intermittent, often discontinuous, and initially confined to warm grasslands and open woodlands across southern Asia. During the Early'Pleistocene, the effects of the uplift of Tibet and the inception of the monsoon were muted by the low-amplitude nature of northern hemisphere glaciations. By the Middle Pleistocene, further uplift, stronger monsoonal circulation, and higher-amplitude, glacial-interglacial cycles made much of Southwest and Central Asia more arid than previously. Two other Mid-Pleistocene developments were important: first, the appearance of Acheulean assemblages, possibly as far east as southern China; and secondly, the first appearance of hominids at latitudes 40$45^{\circ} \mathrm{N}$ during interglacial episodes. Hominid dispersals in both Europe and Asia were probably broadly similar in that hominids did not habitually live beyond $40^{\circ} \mathrm{N}$ until c. 500 kya. Rather than dividing Asia longitudinally into areas east or west of the Movius line, latitudinal divisions between warm/hot and cool/cold environments might be more appropriate. Keywords: hominid dispersals, colonization, Asia, monsoon, loess, Lower Pleistocene, Middle Pleistocene, ice ages, Movius Line.
\end{abstract}

